\title{
MENINGKATKAN KUALITAS PEMBELAJARAN MATEMATIKA SEKOLAH DASAR MELALUI LESSON STUDY
}

Tatang Herman (hermantatang@ymail.com)

Universitas Pendidikan Indonesia (UPI)

\begin{abstract}
In order to improve the quality of primary mathematics teaching and learning, many efforts had be done by researchers. Otherwise, it is difficult to implement research findings in the schools setting to improve teaching outcomes. This action research attempts to explore the implementation of lesson study in order to improve the quality of teaching and learning mathematics in primary schools. The study was conducted in some private and public primary schools arround Bandung. The study found that lesson study becomes one of the most effective ways to improve the quality of primary mathematics teaching and learning through teachers' professional development program.
\end{abstract}

Keywords: action research, improving teaching and learning quality, lesson study in primary mathematics

\begin{abstract}
ABSTRAK
Dalam rangka meningkatkan kualitas matematika dasar pengajaran dan pembelajaran, berbagai upaya telah dilakukan oleh peneliti. Jika tidak, sulit untuk menerapkan hasil penelitian di sekolah pengaturan untuk meningkatkan hasil pengajaran. Penelitian ini mencoba untuk mengeksplorasi pelaksanaan lesson study dalam rangka meningkatkan kualitas pengajaran dan pembelajaran matematika di sekolah dasar. Penelitian ini dilakukan di beberapa SD di seluruh sekolah swasta dan negeri Bandung. Studi ini menemukan bahwa lesson study menjadi salah satu cara yang paling efektif untuk meningkatkan kualitas matematika dasar pengajaran dan pembelajaran melalui program pengembangan profesi guru.
\end{abstract}

Kata kunci: lesson study dalam matematika primeraction research, meningkatkan pengajaran dan kualitas pembelajaran, penelitian tindakan

Salah satu faktor yang menyebabkan sulitnya menerapkan inovasi pembelajaran di sekolah adalah resistennya guru dalam melalukan perubahan dan inovasi. Salah satu upaya yang dapat dilakukan untuk mengatasi resistensi di lapangan adalah melalui kegiatan kolaborasi lesson study. Kegiatan lesson study sebenarnya bukanlah program baru di Indonesia, sebab program kerjasama peningkatan pembelajaran ini merupakan kelanjutan dari kegiatan "piloting" yang pernah dilakukan Universitas Pendidikan Indonesia, khususnya Fakultas Pendidikan Matematika dan IImu Pengetahuan Alam (FPMIPA) , bersama Japan International Cooperation Agency (JICA). Lesson study dinilai sebagai rahasia keberhasilan Jepang dalam peningkatan kualitas pendidikannya (Stigler \& Hiebert, 1999). Prinsip utama lesson study adalah peningkatan kualitas pembelajaran 
secara bertahap dengan cara belajar dari pengalaman sendiri dan orang lain dalam melakukan kegiatan pembelajaran.

Dalam lesson study tidak hanya guru yang melaksanakan pembelajaran yang dapat memetik manfaat, namun para observer (guru lain/mitra, mahasiswa, dosen dan pihak-pihak lain) yang hadir pada saat pembelajaran. Dengan mengamati kegiatan pembelajaran yang dilakukan seorang guru, observer didorong untuk merefleksikan pembelajaran yang dilaksanakannya dan bagaimana meningkatkan kualitasnya. Oleh karena itu, lesson study sesungguhnya merupakan forum belajar bersama untuk saling belajar dari pengalaman guna meningkatkan kualitas pembelajaran.

Beberapa penelitian yang telah dilakukan menunjukkan bahwa guru sulit sekali berubah (Davis, 2003) dan bahwa mahasiswa calon guru lebih banyak belajar dari bagaimana mereka diajar oleh para dosennya dan bukan dari apa yang dipaparkan dosen tentang cara mengajar yang baik (Mellado, 1998). Karena lesson study merupakan sumber contoh-contoh nyata tentang bagaimana melakukan pembelajaran, partisipasi sebagai observer dalam lesson study atau mengamati rekaman video lesson study dapat digunakan untuk meningkatkan kemampuan mengajar guru dan mahasiswa calon guru.

Penelitian ini bertujuan untuk mengkaji peningkatan kemampuan melaksanakan pembelajaran (kompetensi pedagogik dan kompetensi profesional) guru SD yang terlibat dalam kegiatan lesson study. Lebih jauh penelitian ini ingin mendapatkan informasi kegiatan serta betuk partisipasi guru dalam lesson study yang dapat memperbaiki kemampuan guru dalam meningkatakan kualitas pembelajaran matematika di SD.

\section{METODOLOGI}

Penelitian ini merupakan penelitian tindakan (action research), dengan tahapan sebagai berikut: (1) Workshop kepada guru-guru tentang lesson study (2) Observasi pembelajaran yang dilakukan oleh salah seorang guru, (3) Workshop pengembangan komponen pembelajaran (plan), (4) Pelaksanaan open lesson dan refleksi (Do \& See), dan (5) Evaluasi kegiatan lesson study. Data penelitian diambil dari rekaman pelaksanaan pembelajaran, lembar observasi dan wawancara, serta tes hasi belajar siswa. Proses pembelajaran tersebut juga direkam dengan menggunakan video kamera untuk keperluan analisis lebih lanjut. Setelah pelaksanaan Kegiatan Belajar Mengajar akan dilakukan diskusi multi arah anatara guru dengan para observer.

Saat wawancara rekaman video pembelajaran diperlihatkan kembali kepada guru/calon guru agar dapat mengamati kelemahan dan kekurangan yang mereka lakukan selama pembelajaran. Wawancara diarahkan pada persepsi guru/calon guru terkait ide/pandangan mereka dalam melaksanakan pembelajaranserta manfaat yang dirasakan guru/calon guru terhadap lesson study.

Penelitian dilaksanakan di empat SD, yaitu SD Laboratorium UPI Bumi Siliwang (BS), SD Negeri Isola 2, SD Al-Amanah Lembang dan SD Laboratorium UPI kampus Cibiru. Pemilihan sekolah didasarkan pada karakteristik sekolah yang bersangkutan sehingga memiliki keragaman yang tinggi. SD Lab UPI mewakili sekolah yang dalam proses peningkatan dibina langsung oleh UPI. SDN Isola 2 mewakili SD kelompok menengah. SD IT Al-Amanah Lembang mewakili SD yang relatif jauh dari UPI dan kurang mendapatkan pembinaan. SD Lab UPI kampus Cibiru mewakili SD yang dibina oleh kampus Daerah.

Instrumen yang digunaan dalam penelitian ini adalah:

1. Lembar observasi untuk menjaring kompetensi pedagogik dan profesional yang ditunjukkan guru dalam proses pembelajaran secara progresif. 
2. Pedoman wawancara untuk menjaring pandangan guru mengikuti program lesson study serta pemahamannya tentang pelaksanaan dan manfaat lesson study yang telah dilakukan.

3. Pedoman khusus untuk menganalisis video pembelajaran.

4. Perangat tes untuk mengukur peningkatan kualitas hasil pembelajaran.

\section{HASIL DAN PEMBAHASAN}

Kegiatan Workshop Lesson Study

Sebelum peleksanaan kegiatan lesson study dilakukan di empat sekolah, yaitu SD Lab UPI Kampus Bumi Siliwangi, SD Al-Amanah Lembang, SDN Isola 2, dan SD Lab UPI Kampus Cibiru, terlebih dahulu dilakukan workshop tentang lesson study. Peserta workshop adalah guru kelas satu sampai dengan kelas enam (6 guru) dan kepala sekolah dari setiap SD peserta. Kegiatan workshop ini dilakukan sehari penuh (8 jam) pada tanggal 24 Agustus 2009 bertempat di gedung FPMIPA Kampus UPI, mulai pukul 08.00 s.d. 15.00. Kegiatan workshop diawali dengan penjelasan mekanisme dan teknis pelaksanaan lesson study, tujuan lesson study, sasaran dari kegiatan lesson study, tren pembelajaran SD masa kini. Melalui kegiatan workshop ini, diharapkan guru dan kepala sekolah memiliki wawasan yang memadai mengenai lesson study, memiliki motivasi untuk meningkatkan kualitas pembelajaran dan profesionalitas guru, serta memiliki gambaran pelaksanaan lesson study yang akan dilakukan bersama-sama di masing-masing sekolah.

Kegiatan workshop diakhiri dengan diskusi penyusunan draf rencana pembelajaran yang akan dilakukan dalam open lesson di masing-masing sekolah. Kegiatan ini menghasilkan draf Rencana Pelaksanaan Pembelajaran (RPP), Lembar Kerja Siswa (LKS), dan lembar penilaian pembelajaran. Draf perangkat rencana pembelajaran ini selanjutnya disempurnakan dalam lokakarya lanjutan di masing-masing sekolah dengan peserta guru di setiap sekolah masing-masing.

Observasi Pembelajaran Sebelum Kegiatan Lesson study

Sebelum pelaksanaan kegiatan lesson study terlebih dahulu dilakukan observasi pembelajaran di masing-masing SD. Selain itu kegiatan pembelajaran direkam sehingga diperoleh video pembelajaran di setiap SD. Hal ini dilakukan untuk mengetahui kondisi awal kegiatan pembelajaran yang biasa dilakukan guru di masing-masing sekolah.

Berdasarkan hasil pengamatan pembelajaran dan analisis video diperoleh informasi bahwa kegiatan pembelajaran di setiap sekolah umumnya masih didominasi oleh kegiatan guru menjelaskan. Interaksi murid-guru umumnya masih lemah dan KBM umumnya masih diwarnai kegiatan guru menerangkan konsep dan memberikan latihan/tugas. Dalam kegiatan pembelajaran di kelas, beberapa guru mencoba menerapkan kegiatan belajar kooperatif (kelompok). Hasil pengamatan menunjukkan bahwa kegiatan pembelajaran kelompok belum efektif ditinjau kinerja dan interaksi murid dalam kelompok. Belum tampak murid melakukan berbagi gagasan (sharing idea) dan murid belajar dari sesama murid. Kegiatan kelompok masih didominasi oleh murid yang berkemampuan lebih di dalam kelompoknya. Selain itu pembelajaran kelompok tampak lebih menyita waktu.

\section{Perencanaan Pembelajaran dalam Open Lesson (Plan)}

Perencanaan pembelajaran untuk open lesson pertama kali didiskusikan dalam kegiatan lokakarya (workshop). Penyusunan perangkat pembelajaran ini dilakukan guru secara berkelompok. Pembentukan kelompok dilakukan berdasarkan guru yang mengajar pada kelas yang sama dari setiap sekolah peserta. Jadi masing-masing kelompok terdiri atas 4 orang dan semuanya ada 6 
kelompok, yaitu kelompok guru kelas 1, 2, 3, 4, 5, dan 6. Dalam diskusi disepakati bahwa pelajaran yang dilakukan dalam open lesson adalah matematika di kelas bawah (tematik) dan di kelas atas.

Kegiatan diskusi kelompok diawali dengan peninjauan silabus sesuai dengan materi yang akan diberikan di masing-masing sekolah, kemudian penyusunan RPP, LKS, dan alat penilaian pembelajaran. Melalui kegiatan kelompok ini diperoleh draf komponen pembelajaran untuk matematika. Draf komponen pembelajaran ini selanjutnya direvisi dan dilengkapi oleh kelompok guru di masing-masing sekolah.

\section{Pelaksanaan Open Lesson (Do) dan Refleksi (See)}

Pelaksanaan open lesson dan refleksi dilakukan di keempat SD mengikuti jadwal berjalan di masing-masing sekolah. Kegiatan open lesson dilakukan di setiap sekolah dengan masing-masing guru model berasal dari sekolah tempat open lesson dilaksanakan. Berikut ini dieskripsikan kegiatan open lesson secara umum yang terlaksana di setiap sekolah beserta refleksi dari kegiatan pembelajaran yang dilakukan.

Secara umum kegiatan pembelajaran menarik perhatian murid, mendorong murid belajar sungguh-sungguh dan disiplin. Guru memulai pembelajaran dari apa yang diketahui anak. Guru kurang memperhatikan anak dan tidak melakukan pengamatan ke setiap kelompok yang sedang bekerja sama. Anak-anak yang tidak terperhatikan guru, tampak kurang serius belajar dan cenderung mengganggu anak lain yang sedang belajar. Partisipsi anak dalam kegiatan kelompok tidak terkontrol dan kurang terperhatikan, sehingga yang bekerja dalam kelompok hanya beberapa oarang saja.

Disamping itu, Lembar Kegiatan Murid yang disusun kurang menantang sehingga kegiatan kelompok tampaknya monoton dan kurang termotivasi.

Kegiatan pembelajaran umumnya belum mengangkat aspek koneksi matematis. Misalnya dalam suatu pembelajaran yang dibahas tidak terfokus pada sifat kubus saja, namun dipadukan dengan sifat balok. Dalam satu kesempatan kegiatan anak langsung belajar dua sub pokok bahasan dan dilakukan dengan membandingkan kesamaan dan perbedaan sifat-sifat dari bangun kubus dan balok, sebab pada hakekatnya kubus juga merupakan balok yang memiliki sifat khusus. Dengan demikian, pembelajaran dapat lebih bermakna bagi anak,.

Umumnya kegiatan pembelajaran sudah kondusif, murid mengikuti pembelajaran dengan seksama, mengacungkan tangan apabila ditanya guru, dan menyiapkan tugas yang diperintahkan guru. Guru tampak dapat mengatur kelas dan menguasai dengan baik. Murid menunjukkan aktivitas belajar yang responsif dan spontan, beberapa murid berani mengajukan pertanyaan bila ada hal yang belum jelas, dan guru pun tampak dapat memberikan tanggapan yang positif. Interaksi murid dengan murid dalam kelompok umunya masih lemah.

Namun umumnya kegiatan masih didominasi oleh kegiatan mengajar guru. Aktivitas belajar untuk dapat mengalami dan menemukan sendiri masih belum muncul. Kegiatan pembelajaran yang diharapkan adalah aktivitas belajar murid melalui proses inkuiri, sehingga diharapkan murid sendiri yang mengonstruksi pengetahuannya melalui aktivitas. Aktivitas murid yang terjadi dalam pembelajaran pada tataran merespon apa yang diminta dan diperintahkan guru. Sepintas guru tampak terburu-buru. Karena waktu yang tersedia cukup singkat, keterkaitan antar beberapa subkegiatan belajar kurang fokus pada judul tema yang diambil. Akibat lainnya adalah ketercapaian dari indikator pembelajaran menjadi pertanyaan yang meragukan beberapa pengamat. Dalam pembelajaranpun tujuan pembelajaran ini belum diakses baik dalam proses maupun di akhir kegiatan pembelajaran. 
Keberhasilan dari lesson study bukanlah prestasi seseorang dalam waktu sesaat, namun merupakan pencapaian hasil dari suatu proses kolaborasi banyak pihak terutama antar sesama guru, kepala sekolah, dan pihak lain yang memiliki kepentingan yang sama dalam meningkatkan kualitas pendidikan, yang dilakukan secara berkesinambungan. Kesungguhan tekad, keterbukaan, dan kebersamaan semua pihak yang berkolaborasi inilah yang akan menentukan kegiatan lesson study. Namun hal lain yang perlu mendapat perhatian adalah murid kurang diberi kesempatan untuk bertanya. Pertanyaan yang sering muncul hanya satu arah yaitu dari guru kepada murid.

Umumnya murid mulai belajar setelah guru melakukan apersepsi dengan memperlihatkan gambar sebagai media pembelajaran. Guru di kelas rendah lebih tampak menunjukkan intonasi suara, mimik dan ekspresi, serta melakukan demonstrasi. Penggunaan media dalam pembelajaran dapat memudahkan para murid untuk memahami materi yang diberikan dan membangkitkan keingintahuan murid terhadap materi tersebut. Kemampuan guru dalam memperlakukan murid dengan kesabaran, memberikan kebebasan kepada murid untuk mengembangkan kreativitasnya terutama saat membuat berbagai bentuk dari plastisin.

\section{a. Peningkatan Kualitas Pembelajaran}

Seperti sudah dikemukakan di atas, bahwa dalam kegiatan lesson study ini dilakukan open lesson sebanyak empat kali, masing-masing satu kali bertempat di sekolah partisipan. Frekuensi open lesson yang telah dilakukan dirasakan kurang oleh semua guru peserta, terutama guru model. Berdasarkan evaluasi kegiatan, motivasi guru dalam kegiatan lesson study ini dirasakan sangat tinggi. Pertama, kehadiran gurudalam setiap kali pertemuan yang dilaksanakan, baik dalam perencanaan ataupun dalam open lesson, mencapai 100\%. Kedua, partisipasi guru dalam setiap kesempatan diskusi menunjukkan mereka sungguh-sungguh dalam melaksanakan kegiatan ini, terutama dalam mengemukakan pengalaman, tanggapan, dan masukan/saran, serta mengajukan pertanyaan apabila dihadapkan pada hal-hal yang belum jelas atau kurang mengerti.

Ketiga, keseriusan mereka dalam mempersiapkan dan melaksanakan open lesson . Kegiatan pembelajaran yang secara bersama-sama diamati, dianalisis, dan dibahas oleh tim, dipersiapkan dengan menampilkan segenap potensi yang mereka miliki, sehingga para kepala sekolah pun berkomentar akan sulitnya melaksanakan pembelajaran seperti yang telah dilakukan dalam open lesson .

Kegiatan lesson study oleh para guru sebagai kegiatan yang benar-benar dirasakan manfaatnya. Dalam lesson study, kegiatan kolaboratif yang dilakukan guru mulai dalam perencanaan pembelajaran. Rencana pembelajaran disusun secara bersama dengan memperhatikan potensi yang dimiliki, kekurangan yang ada, konteks atau tema yang tepat, media, bahan, scenario/alur pembelajaran, serta upaya-upaya lain agar pembelajaran dapat berlangsung secara efektif dan efesien. Berdasarkan hasil wawancara dan diskusi dengan guru-guru tentang kegiatan yang dilakukan dalam perencanaan pembelajaran, pengkajian terhadap komponen rencana pembelajaran seperti ini jarang atau bahkan tidak pernah dilakukan sebelumnya. Dalam lesson study, kegiatan pengkajian perangkat rencana pembelajaran seperti ini merupakan langkah penting yang harus dilakukan. Kemahiran guru dalam menyiapkan komponen pembelajaran ini merupakan langkah awal yang perlu untuk mencapai pembelajaran berkualitas. Melalui rancangan pembelajaran yang sudah disusun dan dibahas secara kolaboratif, dalam kegiatan lesson study, pelaksanaan pembelajaran dilakukan melalui open lesson. Dalam kegiatan open lesson, salah seorang guru harus menjadi guru 
model dan melakukan implementasi pembelajaran sesuai dengan rencana yang sudah disusun bersama-sama. Semua partisipan lesson study akan bertindak sebagai observer dalam kegiatan open lesson. Hal ini yang mendorong guru model untuk melaksanakan pembelajaran sebaik-baiknya.

Tahap berikutnya yang harus dilakukan dalam kegiatan lesson study adalah refleksi. Dalam bagian ini kegiatan pembelajaran yang telah dilakukan secara terbuka didiskusikan kekuatannnya, kelemahannya, hal-hal yang seharusnya dilakukan, hal-hal tidak seharusnya dilakukan, saran-saran, dan hal lainnya berkaitan dengan pembelajaran yang telah dan atau yang akan dilakukan. Kesiapan guru model dalam melakukan evaluasi diri, menerima masukan, saran, atau kritik, sangatlah diperlukan oleh seorang guru partisipan lesson study.

Dari keseluruhan kegiatan lesson study yang telah dilakukan dapat dikemukakan bahwa semua partisipan mengikuti kegiatan dengan serius dan menunjukkan dedikasi yang tiggi dalam melakukan seluruh kegiatan lesson study. Hal ini ditunjukkan dengan tingginya tingkat kehadiran guru yang mencapai rata-rata 95\%, dan berpartisipasi aktif dalam setiap diskusi, karena setiap peserta diharuskan melaporkan hasil diskusi/observasi dan memberikan saran. Secara kualitatif kualitas proses pembelajaran yang dilakukan guru lebih baik daripada kualitas proses pembelajaran sebelum tindakan lesson study ini dilakukan. Hasil analisis video pembelajaran sebelum lesson study dilakukan dan ketika lesson study dilakukan berubah, terutama dalam hal aktivitas belajar murid, pengajuan pertannyaan guru dan murid, respon/tanggapanmurid, serta interaksi murid-guru dan murid-murid.

Beberapa fase kegiatan yang dilakukan dalam lesson study, seperti perencanaan dan persiapan pembelajaran (plan), implementasi pembelajaran yang dilakukan dalam bentuk open lesson (do), dan refleksi pembelajaran (see) adalah merupakan rangkaian kegiatan yang biasa dilakukan oleh seorang guru dalam kesehariannya. Di balik itu semua ada hal lainnya yang tidak biasa dilakukan guru, yaitu bekerja secara kolaboratif Kekuatan dari kegiatan lesson study adalah bagaimana kegiatan yang biasa dilakukan guru itu dikaji, dielaborasi, dan dikembangkan sehingga semua potensi yang dimiliki dapat diberdayakan secara sinergis sehingga menghasilkan suatu kegiatan pembelajaran yang lebih berkualitas dari kegitan sebelumnya. Suatu kegiatan pembelajaran yang direncanakan dan disiapkan dengan seksama, pelaksanaannya dieveluasi dan direfleksi, menghasilkan suatu yang lebih baik.

Melalui kegiatan lesson study ini ditunjukkan bahwa kemampuan guru dalam merencanakan dan melaksanakan pembelajaran berproses menjadi lebih baik sesuai dengan tuntutan kurikulum. Kegiatan lesson study ini tidak secara khusus berfokus pada pengukuran peningkatan hasil belajar siswa, namun lebih berorientasi pada perbaikan proses pembelajaran. Oleh karena itu, dalam penelitian ini penilaian yang dilakukan lebih menekankan pada on-going assessment. Berdasarkan hasil observasi dan refleksi pembelajaran, secara proses kualitas kegiatan pembelajaran lebih baik dari kegiatan-kegiatan sebelum kegiatan lesson study ini dilakukan. Keberhasilan dari lesson study bukanlah prestasi seseorang dalam waktu sesaat, namun merupakan pencapaian hasil dari suatu proses kolaborasi banyak pihak terutama antar sesama guru, kepala sekolah, dan pihak lain yang memiliki kepentingan yang sama dalam meningkatkan kualitas pendidikan, yang dilakukan secara berkesinambungan. Kesungguhan tekad, keterbukaan, dan kebersamaan semua pihak yang berkolaborasi yang menentukan keberhasilan lesson study. Selain para guru, kepala sekolah, pengawas, dan ahli dari institusi terkait seperti dosen Lembaga Pendidikan Tenaga Kependidikan (LPTK), pihak lain yang bergabung adalah komite sekolah, Lembaga Penjamin Mutu Pendidikan (LPMP), dan Dinas Pendidikan Daerah. 
Telah dikemukakan di atas bahwa kegiatan lesson study merupakan kegiatan kolektif dan dalam interval waktu yang cukup. Lesson study yang dilakukan dalam penelitian ini relatif singkat, yaitu sekitar tiga bulan, sehingga kebanyakan partisipan, berpendapat kegiatan ini perlu dilanjutkan. Idealnya, kegiatan lesson study harus diprogramkan dengan baik berdasarkan permasalahan yang dihadapi, dengan indikator keberhasilan yang terukur secara akurat. Adanya keterbatasan waktu ini, untuk mengukur keberhasilan kegiatan tidak dilakukan menggunakan instrumen tes, namun menggunakan asesmen proses. Berdasarkan evaluasi proses ini, hasil penelitian menunjukkan bahwa lesson study dirasakan sebagai kegiatan yang mengenai sasaran dalam meningkatkan kompetensi guru, khususnya kompetensi guru dalam merancang dan melaksanakan pembelajaran (kompetensi pedagogis) dan kompetensi guru dalam materi subjek (kompetensi profesional).

Dalam diskusi terakhir yang dilakukan, seluruh partisipan bermaksud melanjutkan kegiatan lesson study ini dengan menjaga kebersamaan di antara mereka untuk menjadikan fenomena pembelajaran yang dilakukan di kelas yang harus dipelajari, dikaji, dan dikembangkan secara berkelanjutan untuk mendapatkan proses dan hasil yang lebih baik secara terus menerus. Apabila kegiatan seperti ini dilanjutkan secara kontinu, kompetensi guru akan terkembangkan terus, sehingga kualitas pembelajaran akan meningkat. Dengan demikian, lesson study dapat dijadikan sebagai program dalam peningkatan profesionalitas guru secara berkelanjutan.

\section{KESIMPULAN DAN SARAN}

Kegiatan lesson study dapat dilakukan di SD untuk memperbaiki kemampuan guru dalam merencanakan dan melaksanakan pembelajaran matematika. Dalam lesson study seorang guru harus memiliki komitmen yang tinggi, berpartisipasi aktif dalam setiap bagian kegiatan dilandasi semangat dan kemauan yang tinggi, terbuka menerima dan memberi masukan (open-minded), selalu berupaya untuk memperbaiki diri sendiri secara kontinu, dan mampu bekerja kolaboratif dengan semua pihak yang terlibat dalam kegiatan lesson study. Keberhasilan dari lesson study tidak hanya prestasi seorang guru atau kepala sekolah, namun merupakan pencapaian hasil dari suatu proses kolaborasi banyak pihak terutama antar sesama guru, kepala sekolah, dan pihak lain yang memiliki kepentingan yang sama dalam meningkatkan kualitas pendidikan, yang harus dilakukan secara berkesinambungan. Dengan demikian, agar lesson study dapat terlaksana secara optimal, setiap guru harus memberikan dan menampilkan yang terbaik, serta pihak sekolah dan yang berkepentingan harus mampu mensinergikan semua komponen yang terlibat dalam kegiatan.

\section{REFERENSI}

Davis, K. S. (2003). "Change is hard": What science are telling us about reform dan teacher learning of innovative practises. Science and education, 87(1), 3-30.

Fraenkel, J. R., \& Wallen, N. E. (1990). How to design and evaluate research in education. San Francisco: Mc. Graw-Hill Pub. Co.

Hinduan, A. A. (2005). Meningkatkan profesionalisme guru IPA di sekolah. Makalah disajikan dalam seminar nasional pendidikan IPA II, Bandung, 23 Juli 2005.

Mellado, V. (1998). The classroom practise of preservice teacher and their cinception of teaching and learning. Science education, 82, 197-214.

Oser, F., \& Patry, J. L. (1990). Choreographien unterrichtlichen lernens: Basismodelle des unterrichts [Choreographies of teaching and learning: Basic models of teaching]. Freiburg:

Paedagogisches Institut der Universitaet Freiburg. 
Rustaman, N., Widodo, A., Anggraeni, S., \& Junaengsih, N. (2005). Evaluasi pelaksanaan kegiatan piloting biologi. FPMIPA UPI: Tidak diterbitkan.

Saito, E. (2004). Indonesian lesson study in practice: Case study of IMSTEP. Paper disajikan dalam workshop bagi guru-guru Matematika dan sains. Bandung.

Stigler, J. W., \& Hibert, J. (1999). The teaching gap: Best ideas from the world's teachers for improving education in the classroom. New York: the free Press. 